Developments in German Politics 2 


\section{Developments titles available from Macmillan}

Laura Cram, Desmond Dinan and Neill Nugent (eds) DEVELOPMENTS IN THE EUROPEAN UNION

Patrick Dunleavy, Andrew Gamble, Ian Holliday and Gillian Peele (eds) DEVELOPMENTS IN BRITISH POLITICS 6

Peter A. Hall, Jack Hayward and Howard Machin (eds) DEVELOPMENTS IN FRENCH POLITICS (Revised edition)

Gillian Peele, Christopher Bailey, Bruce Cain and B. Guy Peters (eds) DEVELOPMENTS IN AMERICAN POLITICS 3

Martin Rhodes, Paul Heywood and Vincent Wright (eds) DEVELOPMENTS IN WEST EUROPEAN POLITICS

Gordon Smith, William E. Paterson and Stephen Padgett (eds) DEVELOPMENTS IN GERMAN POLITICS 2

Stephen White, Judy Batt and Paul Lewis (eds) DEVELOPMENTS IN CENTRAL AND EAST EUROPEAN POLITICS 2

Stephen White, Alex Pravda and Zvi Gitelman (eds) DEVELOPMENTS IN RUSSIAN POLITICS 4

\section{Of Related Interest}

Ian Holliday, Andrew Gamble and Geraint Parry (eds) FUNDAMENTALS IN BRITISH POLITICS

If you have any comments or suggestions regarding the above or other possible Developments titles, please write to Steven Kennedy, Publishing Director, Macmillan Press Ltd,

Houndmills,Basingstoke RG21 6XS, UK or e-mail

s.kennedy@macmillan.co.uk 


\title{
Developments in German Politics 2
}

\author{
Edited by \\ Gordon Smith \\ William E. Paterson \\ Stephen Padgett
}

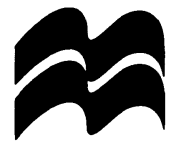


Selection, Introduction and editorial matter (C) Gordon Smith, William E. Paterson and Stephen Padgett 1996

Individual chapters (in order) (C) Gert-Joachim Glaeßner, Russell J. Dalton, Gordon Smith, Charlie Jeffery, Klaus H.

Goetz, Roland Sturm, William E. Paterson, Emil J. Kirchner, Adrian Hyde-Price, Kenneth Dyson, Christopher Flockton, Stephen Padgett, Steen Mangen, Eva Kolinsky, Peter Cullen, Peter Pulzer 1996

All rights reserved. No reproduction, copy or transmission of this publication may be made without written permission.

No paragraph of this publication may be reproduced, copied or transmitted save with written permission or in accordance with the provisions of the Copyright, Designs and Patents Act 1988, or under the terms of any licence permitting limited copying issued by the Copyright Licensing Agency, 90 Tottenham Court Road, London W1P 9HE.

Any person who does any unauthorised act in relation to this publication may be liable to criminal prosecution and civil claims for damages.

First published 1996 by

MACMILLAN PRESS LTD

Houndmills, Basingstoke, Hampshire RG21 6XS

and London

Companies and representatives

throughout the world

ISBN 978-0-333-65903-8 ISBN 978-1-349-24885-8 (eBook)

DOI 10.1007/978-1-349-24885-8

A catalogue record for this book is available from the British Library.

$\begin{array}{rrrrrrrr}10 & 9 & 8 & 7 & 6 & 5 & 4 & 3 \\ 05 & 04 & 03 & 02 & 01 & & & \end{array}$

This book is printed on paper suitable for recycling and made from fully managed and sustained forest resources.

Copy-edited and typeset by Povey-Edmondson

Okehampton and Rochdale, England

This book is a direct replacement for Developments in German Politics, edited by Gordon Smith, William E. Paterson, Peter H. Merkl and Stephen Padgett, published 1992 by Macmillan Press Ltd. 


\section{Contents}

List of Maps, Figures and Tables $\quad \mathrm{x}$

Preface xii

Notes on the Contributors xiii

Glossary of Party Abbreviations and Political Terms xvii

Map of the Federal Republic of Germany and the Länder xix

1 Introduction 1

The Federal Republic as a 'Normal' State 1

Components of the 'German Model' 2

The Contribution of Politics 3

Sustaining Economic Success 4

Economic Management 5

The Social Consequences of Structural Change 6

Foreign Policy 8

Post-Reunification 9

German Foreign Policy and the Future 10

Part One: The Institutional and Political System

2 Government and Political Order Gert-Joachim Glaeßner 14

The Federal Republic as a Semi-Sovereign State 14

The Constitutional Framework 16

Features of German Federalism 22

Government at the Centre: Parliamentary Institutions 26

The Role of the Chancellor 29

Coalition Government 33

3 A Divided Electorate? Russell J. Dalton 35

Social Cleavages and Voting Behaviour 36

Social Status: East-West Contrasts $\quad 37$

Religious Imbalance 41

Partisan Attachments $\quad 44$

Comparing Political Beliefs 47

The German Electorates 51 
4 The Party System at the Crossroads Gordon Smith 55

The Inherited Structure 55

The 1994 Federal Election: Crumbling of the Model? 57

Contrasts of Party Leadership 61

The Parties in a Two-Bloc System $\quad 64$

Trends in the Länder 68

A 'Cartel' Democracy?

5 The Territorial Dimension Charlie Jeffery 76

The Structures of German Federalism 77

Patterns of Interest Divergence and Policy Differentiation $\quad 79$

Resource Distribution in the Federal System 83

$\begin{array}{ll}\text { Party Politics and the Federal System } & 87\end{array}$

The Länder and the European Union $\quad 90$

A 'Two-Class Federalism' or a 'Differentiated Policy Regime'? 94

6 The Federal Constitutional Court Klaus H. Goetz 96

The Potential of Constitutional Rule $\quad 97$

The Court as a Judicial and Political Institution $\quad 100$

The Court Under Scrutiny 105

Decline of the Basic Law? 111

Acquiescence, Reassertion or Cooperation? The Future of the Court 114

7 Continuity and Change in the Policy-Making Process

Roland Sturm 117

The Decision Makers $\quad 118$

Consensus and Compromise $\quad 120$

The Policy Cycle $\quad 122$

Policy Making $\quad 126$

Recent Developments in Policy-Making 130

Part Two: Germany and the World

8 Beyond Bipolarity: German Foreign Policy in a

Post-Cold-War World William E. Paterson 134

The National Interest Debate 136

The Pull of Memory $\quad 137$

The Civilian Power 140 
Germany and Former Yugoslavia

Germany, the United States and the Gulf War 145

Collapse and Change in the Soviet Union 147

A Global Role for Germany?

Conclusion: The River Bank, the Wild Wood and the Wide World

9 Germany and the European Union: From Junior to Senior Role Emil J. Kirchner

Doubts about the European Union

A Unified Germany Within the EU

EMU: To be or not to be?

Political Integration: A Dream Too Far or the Price for having EMU?

Enlargement: Security Necessity or a German Ploy? 168

German Interest: Intended and Unintended

Consequences

10 'Of Dragons and Snakes': Contemporary German Security

Policy Adrian Hyde-Price

Germany and the European Balance of Power $\quad 174$

The Federal Republic and Cold War Europe 176

Germany and the Post-Cold War Security Agenda 179

NATO: The Bed-Rock of German Security 181

Towards a European Defence and Security Identity? 184

The OSCE and a Co-operative Security System? 186

The Bundeswehr and Out-of-Area Operations 189

A European 'Peace Order' 190

Part Three: The Economy and Social Policy

11 The Economic Order - Still Modell Deutschland?

Kenneth Dyson

The Character of the German Model 196

The Challenge to the German Model 201

Globalisation and Post-Fordism 202

Deepening and Widening the European Union 203

German Reunification and the Opening Up of the East 204

The Response to the Challenge to the German Model 205

Tasks for the Political Actors 208 
12 Economic Management and the Challenge of Reunification Christopher Flockton

Competitiveness and Economic Transformation

Economic Policy and the Dual Economy 214

Market Distortions in the Policy for the East? 217

Budgetary Crises and State Deficits 218

The Welfare State and the Labour Market 221

Economic Restructuring in the East 224

The Treuhand and Privatisation 225

Investment and Liberalisation 229

The Slowness of Reform 231

13 Interest Groups in the Five New Länder Stephen Padgett 233

The Rise of Interest Organisations in the East 234

Organisational Structure $\quad 236$

Interest Group Membership $\quad 239$

Problems of Interest Representation 241

Internal Organisational Life $\quad 242$

Organisation Without a Social Base $\quad 244$

Regional Corporatism $\quad 245$

A Post-Modernist Model? 247

\section{Part Four: Current Issues}

14 German Welfare and Social Citizenship Steen Mangen 250

German Welfare Pluralism 251

Unification and Welfare $\quad 254$

Social Security $\quad 257$

Pensions Reform 258

Consolidating Health Reform $\quad 260$

Resolving the Crisis of Care 262

A Welfare Impasse: Long-Term Unemployment 263

The Last Resort: Social Assistance 264

Insiders-Outsiders: The Welfare State in the

Twenty-First Century 265

15 Women in the New Germany Eva Kolinsky 267

New Germanies and the Emergence of Equality 267

Unification Treaty Agendas 268

Equality Between Promise and Reality: Developments in West Germany 
Education, Employment and Family Roles 270

Decree and Perception: Equality in the Former GDR 272

Women as Working Mothers: Hidden Inequalities 273

Women's Place and State Policy 275

Between Opportunities and Exclusion: Women in the New Germany 276

Family Roles: Continuity and Transformation 280

Incomes and Poverty 281

The New Employment Society 283

16 Crime and Policing in Germany in the 1990s Peter Cullen 286

Developments in Criminal Policy since Reunification 286

Crime and Policing in the Former GDR 286

Countering Right-Wing Violence 289

Organised Crime 290

Policing and Crime Control Strategies in the 1990s 294

European Police Cooperation 298

Constraints, Concerns and Innovation 300

17 Model or Exception - Germany as a Normal State?

Peter Pulzer $\quad 303$

State Formation and the National Question 303

From National Chauvinism to Constitutional Patriotism $\quad 307$

Nationality and Citizenship in the New Germany 311

Nation State and National Interest 313

Guide to Further Reading $\quad 317$

Bibliography $\quad 323$

Index $\quad 344$ 


\section{List of Maps, Figures and Tables}

Maps

1 The Federal Republic of Germany and the Länder xix

2 Germany after $1949 \quad 15$

Figures

2.1 Division and fusion of powers 19

2.2 Legislative competences of the federation 27

3.1 Social values of the German electorate, $1995 \quad 49$

4.1 Performance of left and right blocs, 1987 and 1994

Tables

2.1 Administrative structure of the Federal Republic 23

2.2 Coalitions and federal chancellors, 1949-96 32

3.1 Class voting patterns, $1994 \quad 38$

3.2 Religious voting patterns, $1994 \quad 43$

3.3 The strength of partisanship, 1972-94 47

3.4 Perceived government responsibility for dealing with
political problems

4.1 Elections to the Bundestag, 1949-94 56

4.2 Election results, 1990 and 1994, East and West
Germany

4.3 Aggregate vote of leading parties, 1976-94 60

4.4 Composition of Land governments and Bundesrat seats, 1996

4.5 Party membership and ratio to voters, 1994

5.1 Financial equalisation flows for $1995 \quad 85$

5.2 The parties in the Bundesrat 89

6.1 Proceedings before the Federal Constitutional Court, 1951-94 
7.1 Examples of German policy-making as a three-step decision-making process

12.1 Macroeconomic evolution in the FRG, 1990-95 214

12.2 Public sector revenue, expenditure and balances 219

12.3 Public financial transfers to eastern Germany 220

12.4 Treuhand balance sheet, $1995 \quad 226$

13.1 IG Metall membership, 1991-94 239

14.1 The German welfare system 252

15.1 Labour-market participation of women by age group in the old and new Länder

15.2 Non-employed women and the labour market in the new and old Länder 


\section{Preface}

Our purpose in Developments in German Politics 2 is to provide a series of assessments of current trends in the Federal Republic in what can be described as the 'second phase' of unification. The first phase - the process of reunification and its immediate aftermath - was the subject of the 1992 edition of Developments in German Politics. The problems and perspectives are now somewhat different, and all the contributions to the present volume are entirely new.

Inevitably textbooks are frequently overtaken by events. In drawing largely on current material that is often available only in journal articles and German-language publications, the book seeks to give up-to-date accounts of leading issues. Nevertheless the discussion of individual topics is combined with sufficient background information to make the book accessible for readers who do not have a detailed knowledge of German politics.

As on previous occasions, we wish to thank our contributors German, American and British - for their willing cooperation, despite all their other commitments.

June 1996

Gordon Smith William E. Paterson

Stephen Padgett 


\section{Notes on the Contributors}

Peter Cullen is Jean Monnet Lecturer in European Community Law at the Europa Institute, Faculty of Law, University of Edinburgh. With Klaus Goetz he has edited Constitutional Policy in Unified Germany (1995). He participated in a joint research project on European Police Cooperation at the University of Edinburgh; this has recently been published: in Anderson et al., Policing the European Union, Theory, Law and Practice (1995).

Russell J. Dalton is Professor of Political Science at the University of California, Irvine, and Director of the Center for Study of Democracy at UCI. He is author of The Green Rainbow: Environmental Groups in Western Europe (1994), Citizen Politics in Western Democracies, 2nd edn (1996) and Politics in Germany (1992); and coauthor of Germany Transformed (1981); editor of Germans Divided (1996), The New Germany Votes (1993), Challenging the Political Order: New Social and Political Movements in Western Democracies (1984). He is now working on a comparative study of electoral choice in advanced industrial democracies.

Kenneth Dyson is Professor of European Studies at the University of Bradford, and Co-Director of its European Briefing Unit. He has written widely on European Politics and Political Economy. His recent publications include Elusive Union: the Process of Economic and Monetary Union in Europe (1995) and he is coauthor of Culture First (1996).

Christopher Flockton is Professor of European Economic Studies at the University of Surrey, where his main research and teaching interests cover the German and French economies and European economic integration. He has published widely in these fields.

Gert-Joachim GlaeBner is Professor of German Politics at Humboldt University in Berlin. He has written widely on problems of the communist and post-communist systems, German politics and German unification. Among his books are The German Unification Process (1992); The German Revolution of 1989 (ed. with Ian Wallace) and Demokratie nach dem Ende des Kommunismus (1995). 
Klaus H. Goetz is Lecturer in German Politics at the London School of Economics. $\mathrm{He}$ is the author of Intergovernmental Relations and State Government Discretion (1992), and co-editor of Constitutional Policy in Unified Germany (1995) and A New German Public Sector? (1996). He has recently edited a two-volume collection on German politics for the International Library of Politics and Comparative Government, and is currently writing a monograph on the German State.

Adrian Hyde-Price is Lecturer in Politics and International Relations at the University of Southampton, and was previously a Research Fellow at the Royal Institute of International Affairs. He has published widely on German and European security, and is the author of European Security Beyond the Cold War: Four Scenarios for the Year 2010 (1991) and The International Politics of East Central Europe (1996). He is currently engaged in a research project on 'Security and Identity in Europe'.

Charlie Jeffery is Senior Research Fellow at the Institute for German Studies, University of Birmingham. He has edited a number of books on German federalism, including Federalism, Unification and European Integration (with Roland Sturm) (1993) and The Challenges of Unification: German Federalism in the 1990s (1996). He has written widely on the German Länder, German party politics and regional politics in the EU, including recent articles in Political Studies, West European Politics and Parliamentary Affairs. He is coeditor of Regional and Federal Studies.

Emil Kirchner is Professor of European Studies and Director of the Centre for European Studies, University of Essex. He is the author of Decision making in the European Community: The Council Presidency and European Integration (1992), coauthor of The Recasting of the European Order: Security Architectures and Economic Cooperation (1996) and coeditor of The Future of European Security (1994) and The Federal Republic and NATO: 40 Years After (1991).

Eva Kolinsky is Professor of Modern German Studies and Director of the Centre for the Study of German Culture and Society at Keele University. Recent books include Women in Contemporary Germany (1993), Women in 20th century Germany (1995), Between Hope and Fear. Everyday Life in Post-Unification Germany (1995), Turkish Culture in German Society (1996, with D. Horrocks). She is general 
editor of the German Studies series, coeditor with D. Horrocks of a new book series on Culture and Society in Germany and coeditor of the journal German Politics. Books in progress include Social Transformation and the Family in Post-Communist Germany, Jewish Culture in German Society and a social history of Germany from 1945 to the present.

Steen Mangen convenes the MSc in European Social Policy at the London School of Economics. Apart from research interests in German social security issues, his main research concerns inner city rejuvenation in Europe and the welfare state in post-Franco Spain. He is joint editor of Cross National Research Methods in the Social Sciences (with L. Hantrais, Pinter, 1986) and author of Spain After Franco: Regime Transition and the Welfare State (forthcoming).

Stephen Padgett is Professor of Politics in the School of Politics and Communication Studies at the University of Liverpool. He was previously Reader in the Department of Government, University of Essex. He has written widely on parties and party systems in Europe and Germany, and on public policy in the Federal Republic. His recent publications include Parties and Party Systems in the New Germany (1993) and Adenauer to Kohl the Development of the German Chancellorship (1994). He is an editor of German Politics and Chair of the Association for the Study of German Politics. He has recently completed a project on interest groups in postcommunist Germany, supported by an ESRC Senior Research Fellowship.

William E. Paterson is Director of the Institute for German Studies at the University of Birmingham. From 1990-94 he was Director of the Europa Institute of the University of Edinburgh. Coeditor of German Politics and a member of the Steering Committee of the Königswinter Conference, he has published very widely on a wide range of German and European politics. His book with Simon Bulmer on Germany in the European Union will be published in 1996.

Peter Pulzer is Gladstone Professor Emeritus of Government and Public Administration at the University of Oxford. He has been Eric Voegelin Visiting Professor at the Geschwister-Scholl-Institut, Munich, and Visiting Professor at the University of Potsdam. His most recent books are Jews and the German State. The Political History of a Minority, 1848-1933 and German Politics 1945-1995. 
Gordon Smith is Emeritus Professor of Government at the London School of Economics. He has written extensively on European politics, comparative party systems and German politics. Besides coediting two journals, West European Politics and German Politics, he is associate editor of the International Library of Politics and Comparative Government.

Roland Sturm is Professor of Political Science at the University of Erlangen-Nürnberg. Most of his published work has been concerned with comparative politics, policy studies, political economy, and European, British and German politics. Amongst his most recent books are Politische Wirtschaftslehre (1995), Europäische Forschungs- und Technologiepolitik und die Anforderungen des Subsidiaritätsprinzips (ed., 1996) and Großbritannien (2nd edn, 1996). 


\section{Glossary of Party Abbreviations and Political Terms}

Party Abbreviations

Bündis '90 Alliance '90

CDU Christlich Demokratische Union (Christian Democratic Union)

CSU Christlich-Soziale Union (Christian-Social Union)

FDP Freie Demokratische Partei (Free Democratic Party)

PDS Party for Democratic Socialism (former SED)

SED Sozialdemokratische Partei Deutschlands (Social Democratic Party of Germany)

Other Abbreviations

BDA Bundesvereinigung der Deutschen Arbeitgeberverbände (Federation of German Employers' Associations)

BDI Bundesverband der Deutschen Industrie

BKA Bundeskriminalamt (Federal Criminal Police Office)

CSCE Conference on Security and Cooperation in Europe

DGB Deutscher Gewerkschaftsbund (Federation of German Trade Unions)

ECJ European Court of Justice

EMU Economic and monetary union

FRG Federal Republic of Germany

GDP Gross domestic product

GDR German Democratic Republic

NATO North Atlantic Treaty Organisation

OSCE Organisation for Security and Cooperation in Europe

UN United Nations

VDI Verein Deutscher Ingenieure

WEU Western European Union 


\section{Political Terms}

Bundesbank

Bundesrat

Bundestag

Bundeswehr

Land (pl. Länder)

Mittelstand

Ostpolitik

Rechtsstaat

Sicherheitspolitik

Sonderweg

Sozialstaat

Stasi

Stattpartei

Technologierat

Treuhand

Volkskammer

Volkspartei

Volkspolizei

\section{Federal Bank}

Upper house of federal parliament

Lower house of federal parliament

Federal armed forces

Federal constitutent state

Middle class

Policy towards the East

State based on the rule of law

Security policy

Special path

'Socially responsible' state

East German secret police

Alternative Party

A round table for technology policies

Public Trustee Office

People's Assembly (GDR)

People's party

People's Police 


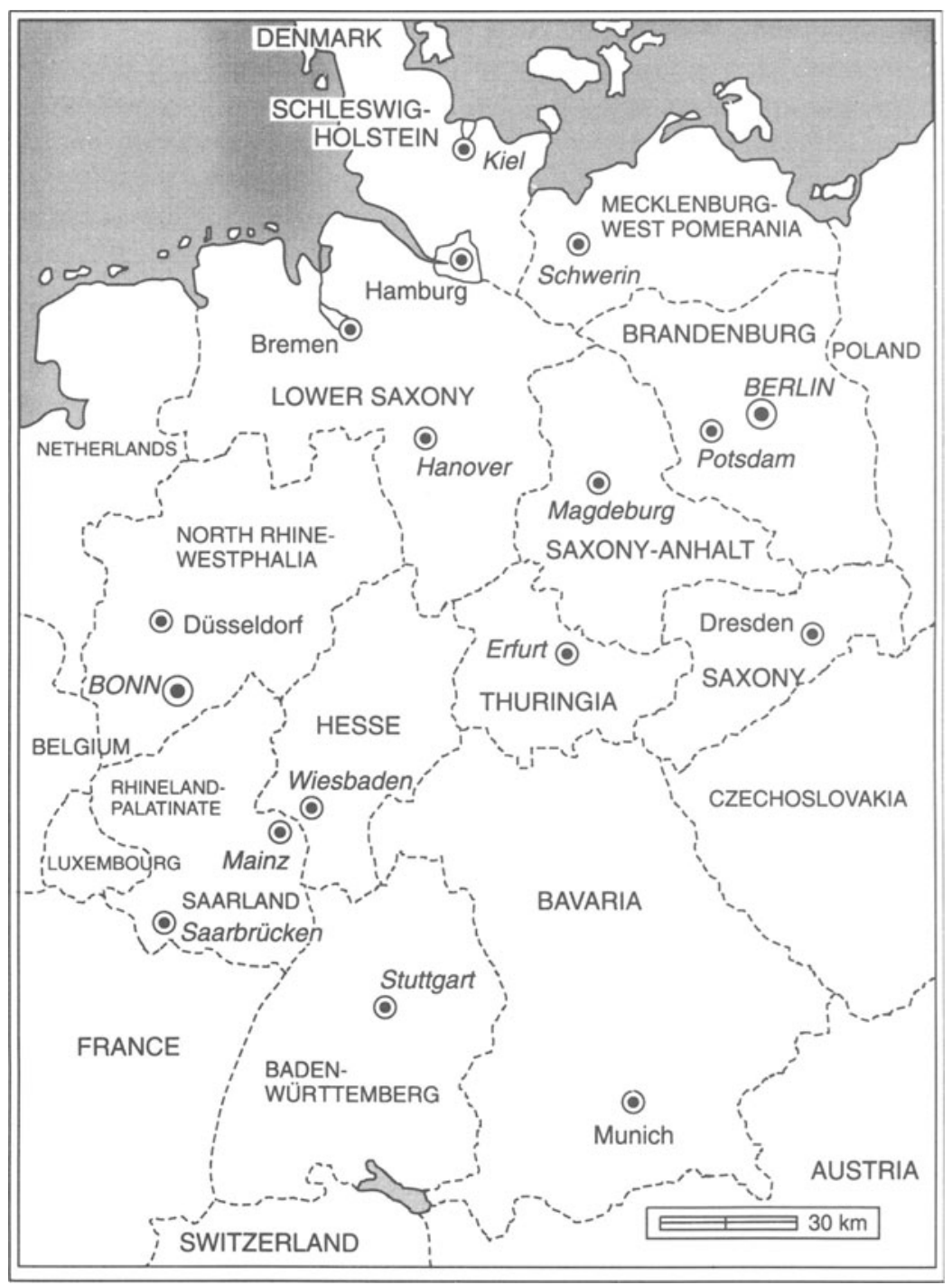

MAP 1 Map of the Federal Republic and the Länder 